\title{
Paulina Ucieklak-Jeż
}

Jan Długosz University in Częstochowa

e-mail: p.ucieklak@o2.pl

\section{INCOME AND EDUCATION \\ AS A SOURCE OF HEALTH INEQUALITY. NEW UE COUNTRIES CASE \\ DOCHODY I EDUKACJA JAKO ŹRÓDŁO NIERÓWNOŚCI ZDROWOTNEJ NA PRZYKŁADZIE NOWYCH KRAJÓW UE}

DOI: $10.15611 /$ pn.2018.510.14

JEL Classification: I10, I14, I15

\begin{abstract}
Summary: The objective of the research was testing the effect of the level of concentration of health needs in the countries of the, so called, New European Union in terms of income and education on the level of health inequality. When planning the study, the following research hypothesis was put forward: H1: there is a relation between meeting the self-reported health needs and the level of education or income of populations of New UE countries. The formulated hypothesis was explicitly confirmed during the analysis of the concentration of the three traits of health care accessibility, which showed that the highest level of concentration indicating a conscious need for taking advantage of specialist medical examinations necessary for the improvement of health was observed in social groups with high education (ED5_8) and income (Q80_100), Q60_80).
\end{abstract}

Keywords: concentration, Herfindahl-Hirschman index, health concentration index, selfreported unmet needs, health needs.

Streszczenie: Celem badania było oszacowanie poziomu koncentracji potrzeb zdrowotnych w krajach tzw. nowej Unii Europejskiej według dochodu wykształcenia oraz ocena poziomu nierówności zdrowotnej. Na etapie projektowania badania postawiono następującą hipotezę badawczą: H1: istnieje związek między zaspokajaniem zgłaszanych potrzeb zdrowotnych a poziomem wykształcenia lub dochodu ludności w nowych krajów UE. Hipoteza ta została potwierdzona w trakcie analizy koncentracji trzech cech dostępności opieki zdrowotnej. Wykazano, że w grupach społecznych o wysokim poziomie wykształcenia (ED5_8) oraz dochodu (Q80_100), (Q60_80) zaobserwowano najwyższy poziom koncentracji, wskazujący na świadomą potrzebę korzystania ze specjalistycznych badań koniecznych dla poprawy zdrowia.

Słowa kluczowe: koncentracja, wskaźnik Herfindahla-Hirschmana, współczynnik koncentracji zdrowia, zgłaszanie niezaspokojonych potrzeb, potrzeby zdrowotne. 


\section{Introduction}

Majority of the developing countries are faced with the problem of inability to satisfy health needs of their inhabitants. Improvement of quality of the health services in satisfying health needs, increasing access to health services in connection with such factors as, for example, technological progress in medicine are universally expected. The problem of quality of health services has been relatively extensively discussed in scientific publications, but from the point of view of everyday functioning of the health protection sector a diagnosis of inequality of health needs in social groups depending on their income or education, determined by an ability of an individual to gain access to health care is also very important.

The objective of the research is to analyse the relationship between income and education and self-reported health care need, as well as the effect of the level of concentration of health needs which can be a source of health inequality. The analysis was carried out for the countries of the, so called, New European Union. Survey data acquired from the European Health Interview Survey (EHIS) ${ }^{1}$ was analysed, i.e.

- Self-reported unmet needs for medical examination, detailed reason and income quintile.

- Self-reported unmet needs for medical examination, detailed reason and educational attainment level.

- Self-perceived health and educational attainment level.

- Self-perceived health and income quintile.

The concept of studying the level of health was based on observations of the authoress [Ucieklak-Jeż 2016a, b], which showed that in the years 2006-2015 the highest inequalities in health state characterised European inhabitants with low level of education and situated in the second income group GIH-Q20-40. This article is a continuation of earlier works which showed the existence of health inequality resulting from income and education level of the population, and the results of which suggested a possibility of higher impact of education than of income of a population on health inequality [Ucieklak-Jeż 2016a, b]. When planning the study, the following research hypothesis was put forward:

H1: there is a relation between meeting the self-reported health needs and the level of education or income of populations of New UE countries. In the hypothesis it is assumed that among other things there is a statistically important relation between income and health inequality, expressed by different level of self-reported health care needs. Verifying hypothesis $\mathrm{H} 1$ assumes not only analysis of relations between unmet aspects of health needs depending on education and income level of a population, but allows to check the state of health inequalities in the countries of the so called New European Union. On the basis of the analysis of differences in unmet health needs in

${ }^{1}$ The European Statistics of Income and Living Condition (EU-SILC) survey contains a small module on health, composed of 3 variables on health status and 4 variables on unmet needs for health care. 
social groups characterised by different levels of education or income, it was assumed, that education determines health inequality stronger than income. The assumption was that the high level of education is clearly connected with health literacy, suggesting that mentality of educated people makes them look for information necessary to satisfy their health needs and to participate consciously in satisfying their own health needs.

The sample group included the following member countries of the so called New European Union: Bulgaria, the Czech Republic, Cyprus, Estonia, Hungary, Latvia, Lithuania, Malta, Poland, Slovakia, Romania ${ }^{2}$, in the years 2007-2015. Selection of the research sample was the result of earlier studies on the assessment of thehealth care efficiency in the New EU.

The Herfindahl-Hirschman health concentration index was used in the analysis to assess inequalities in the level of health needs in time.

\section{Literature review}

Literature indicates studies of inequalities focusing on inequalities determined by age, education, income [Ataguba, Day, McIntyre 2014; Fine et al. 2004; WHO 2013, 2014]. As early as in 1975, while verifying the relation health-income, S.H. Preston proved that a higher income determines higher level of health protection expenses, higher educational possibilities and better quality of the consumed food [Preston 1975]. Results of social studies carried out in different European countries indicate that statistically the lower the socio-economic status (especially including education), the worse health behavior, the lower motivation to introduce changes in lifestyle, hence in health [Korzeniowska, Puchalski (eds.) 2010]. It is universally believed that the lower level of education, treated in the studies as an index of low status, with usually worse living and working conditions is often connected with the worse state of health. Indexes of self-perceived health, i.e., average length of healthy life expectancy HLE, average length of healthy life years HLY, are lower in a social group with low level of education [Bem, Ucieklak-Jeż, Prędkiewicz 2013]. It is important that a low level of education correlates with numerous limitations in taking advantage of medical care due to the lack of financial possibilities and most of all due to the lack of the ability to make use of health care concerning knowledge and competence of individuals, thus less frequent attending preventive examinations, lower stores of knowledge and skills connected with care for one's health, including frequent difficulties in understanding and making use of information concerning health and illness [Puchalski, Korzeniowska 2011].

Recently, more and more often attention is paid to the view that members of the social group characterised by low education are individuals who do not have the ability to make use of health care resulting from their lack of knowledge and competence. This effect leads to worse state of health and is a source of health inequalities. The

\footnotetext{
${ }^{2}$ Slovenia - lack of complete data.
} 
population having higher education has the cognitive and social skills in the field of health promotion - "health literacy", that determine, motivate and give the ability to use health care services, as well as to understand and use information in a way that promotes and enables to maintain good health [Nutbeam 1998, 2000; Sørensen et al. 2012]. It is also an ability of individuals to acquire, analyse and understand basic health information and services necessary to make appropriate health decisions [Nielsen-Bohlman, Panzer, Kindig (eds.) 2004] to control one's health [Kickbusch et al. 2006], make conscious decisions, reduce health risk and increase the quality of life [Zarcadoolas, Pleasant, Greer 2003, 2005, 2006; Ad Hoc Committee on Health Literacy 1999; Paasche-Orlow, Wolf 2007; European Commission 2007; Pavlekovic (ed.) 2008; Ishikawa, Yano 2008; Nielsen-Bohlman, Panzer, Kindig (eds.) 2004]. This ability is strongly related to income and education. Some of the studies confirmed a significantly negative effect of the level of knowledge about health on the result of treatment and safety of the provided health care service. Lack of knowledge, i.e. the so called health literacy is evident in the case of people with low level of general knowledge, poorly educated. Taking appropriate health decisions [Nielsen-Bohlman, Panzer, Kindig (eds.) 2004], an ability to assess the needs and access to health care, understand, evaluate and transfer information [Adams et al. 2009; Freedman et al 2009], as a way to promote, maintain and improve one's state of health in different situations throughout one's life cycle [Rootman, Gordon-El-Bihbety 2008; Yost et al. 2009], requires knowledge which people at a higher level of education certainly have.

Since in spite of the knowledge that it is the attributes of health literacy that are integrated with general education and preceded by the competence necessary to obtain skills connected with healthy everyday life [Mancuso 2008], there are no extensive studies concerning the effect of unmet health needs reported by social groups of different level of education or income on the state of health of a population.

\section{Methodology}

Herfindahl-Hirschman health concentration index was used in the analysis. The Herfindahl-Hirschman health concentration index was worked out at the same time by A.O. Hirschman (1945) and O.C. Herfindahl (1950) and became an universally known index of market concentration used to determine the degree of competitiveness of a company [Ginevičius, Čirba 2007; Pan et al. 2015], export [Meilak 2008], sea container transport market [Matczak 2016], banking services [Tushaj, Hashorva, Thano 2015]. It is a simple statistical measure which is more and more often borrowed, e.g., to calculate concentration of financial and non-financial resources in health protection as well as concentration of shares of all hospitals in the national and regional market [Rhoades 1993], in order to study inequalities in the structure of the hospital market [Rój 2016].

The index is calculated as a sum of squares of shares of individual trait carriers in the general amount of traits. 


$$
H H I=\sum_{i=1}^{n}\left(\frac{i}{n}\right)^{2}=\sum_{i=1}^{n} \omega_{i}^{2}
$$

where: $\omega_{i}-$ share of the $i$-th unmet need for medical examination out of all the possibilities of not meeting health needs.

When the value of the $H H I$ index is lower than 1500 , it means lack of trait concentration, when the value of the $H H I$ is between 1500 and 2000, the trait is moderately concentrated, and when the value of the HHI is 2500 or more, the trait is intensely concentrated ${ }^{3}$.

Moreover, a health concentration index was calculated, determining health inequality depending on education or income.

In this paper, the index was calculated with the use of the data was grouped in 1 to 5 scale, depending on the assessment of the state of health, which allowed to apply the formula:

$$
C=\frac{2}{\mu} \sum_{i=1}^{T} f_{t} \bar{x}_{t} R_{t}-1
$$

where: $\overline{x_{t}}-$ an average state of health in the socio-economic $t$-group,

$f_{t}$ - socio-economic fraction of the $t$-group,

$\mu$ - average state of health, $\mu=\sum_{t=1}^{T} f_{t} x_{t}$,

$R_{t}$ - the rank of the socio-economic $t$-group.

To check the estimates, the index of health concentration was calculated according to the formula:

$$
C=\frac{2 \operatorname{cov}(R, x)}{\mu}
$$

where: $\operatorname{cov}(R, x)$ - covariance variable representing ranks and the state of health, more extensively [Kakwani, Wagstaff, van Doorslaer 1997; World Bank 2004; Mangalore, Knapp, Jenkins 2007; Koolman, van Doorslaer 2004; Fukushige, Ishikawa, Maekawa 2012; Ucieklak-Jeż 2016a, b].

The index can bring values from -1 to +1 , indicating whether health is concentrated around the negative (bad) state of the examined social group $(C<0)$, or positive (good) state $(C>0)$ or is evenly distributed $(C=0)$ on different values of the wellbeing variable [Chen, Roy 2009; Chen, Eastwood, Yen 2007]. The Spearman rank

${ }^{3}$ https://www.justice.gov/atr/horizontal-merger-guidelines-08192010. 
correlation index was applied to calculate the correlation between inequality in unmet health needs at different levels of education or income of a population and the state of health inequality.

\section{Results and discussion}

At the first stage of the study, a comparative analysis of the Herfindahl-Hirschman calculated health concentration index was made. Variables $\left(X_{1}, X_{2}, X_{3}\right)$ characterizing accessibility of health care expressed by the level of unmet health needs, were analyzed.

Table 1. Selected indexes of health care accessibility

\begin{tabular}{|l|l|}
\hline Variable & \multicolumn{1}{c|}{ Definition } \\
\hline$X_{1}$ & $\begin{array}{l}\text { The percentage share of individuals reporting unmet needs of medical } \\
\text { examination due to high cost - too expensive }\end{array}$ \\
\hline$X_{2}$ & $\begin{array}{l}\text { The percentage share of individuals reporting unmet needs of medical } \\
\text { examination due to spatial inaccessibility - too far to travel }\end{array}$ \\
\hline$X_{3}$ & $\begin{array}{l}\text { The percentage share of individuals reporting unmet needs of medical } \\
\text { examination due to long waiting time - waiting list }\end{array}$ \\
\hline
\end{tabular}

Source: own study.

Calculated HHI values for the $X_{\mathrm{ED} 1}, X_{\mathrm{Q} 1}, X_{\mathrm{ED} 2}, X_{\mathrm{Q} 2}, X_{\mathrm{ED} 3}, X_{\mathrm{Q} 3}$, variables, resulting from division of education of natural persons into categories (ED0_2), (ED3_4), $\left(\mathrm{ED} 5\right.$ 8 $^{4}$ and concentration values for five categories of the income level (Q0 20 ), (Q20_40), (Q40_60), (Q60_80), (Q80_100) ${ }^{5}$ in the years 2007 - 2015 (Figures 1-3).

The average value of concentration for the $X_{\mathrm{ED} 1}$ variable is $\overline{H H I_{X_{F D}}}=1929.31$ and for the $X_{\mathrm{Q} 1}$ variable it is $\overline{H H I_{X_{11}}}=2042.25$. It was observed in the studied countries of the so called New European Union that the highest average concentration of unmet the medical examination need was observed for the highest level of a social group with the highest levels of income (Q80_100), (Q60_80) and with the highest level of education (ED5_8). The value of the Herfindahl-Hirschman index for the unmet need of medical examination observed for the trait because of too high costs - too expensive in the group of individuals with the highest income may indicate a conscious need to take advantage of specialist examinations necessary to improve the state of health.

${ }^{4}$ Educational attainment level:_(ED0_2) - pre-primary, primary and lower secondary education, (ED3_4) - upper secondary and post-secondary non-tertiary education, (ED5_8) - first and second stage of tertiary education.

${ }^{5}$ Income quintile group: (Q0_20) - first quintile group of equivalised income, (Q20_40) - second quintile group of equivalised income, (Q40_60) - third quintile group of equivalised income, (Q60_80) - fourth quintile group of equivalised income, (Q80_100) -fifth quintile group of equivalised income. 
too expensive

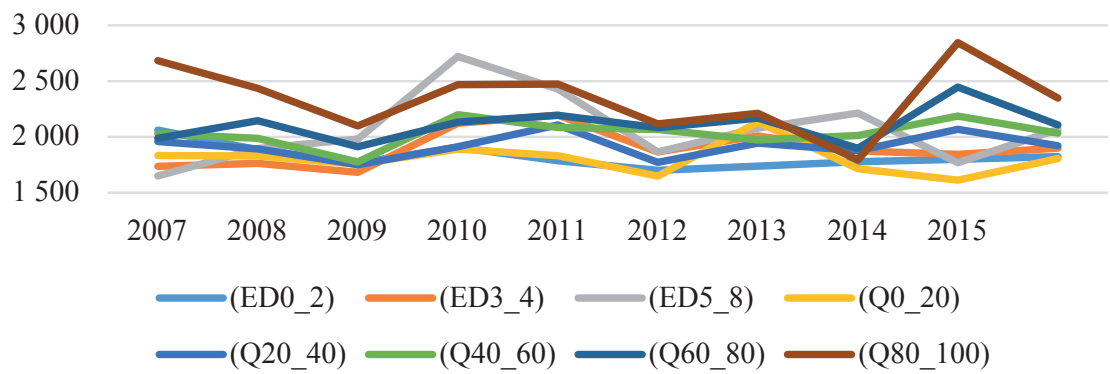

Figure 1. The value of the Herfindahl-Hirschman index concerning the unmet need for medical examination was observed for the trait due to excessively high costs - too expensive with division into categories of education level and income of natural persons in the years 2007-2015

Source: own study.

It may mean, among other things, that there is a higher awareness of the so called health literacy in the need for accessibility of medical examinations and meeting health needs.

It is important that the concentration in categories of education and income level assumed the value of 2500, which denotes moderate force for the analyzed need for medical examination in social subgroups, whereas it is clear that the lowest values of concentration occur on the lowest levels of income and education.

too far to travel

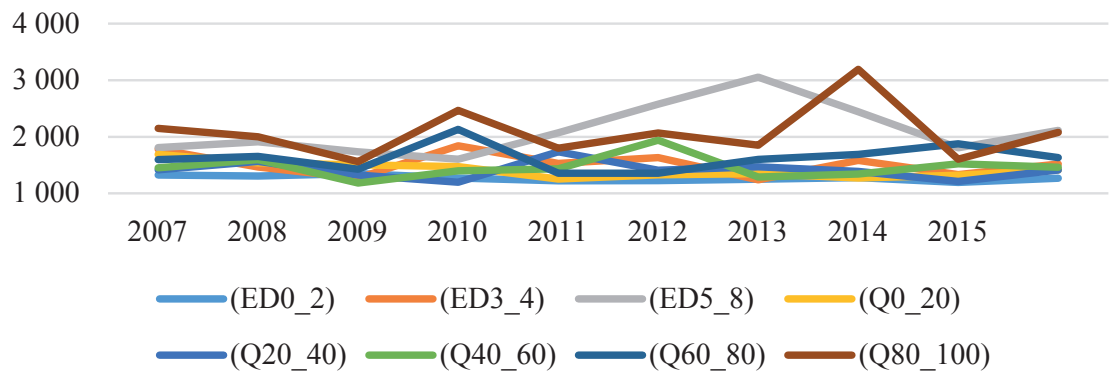

Figure 2. The value of the Herfindahl-Hirschman index concerning the unmet need for medical examination was observed for the trait due to spatial inaccessibility - too fat to travel with division into categories of education level and income of natural persons in the years 2007-2015

Source: own study.

Then the average value of concentration for the $X_{\mathrm{ED} 2}$ variable is $\overline{H H_{X_{K D} 2}}=1633.8$ and for the $X_{\mathrm{Q} 2}$ variable it is $\overline{H H I_{X_{\rho 2}}}=1599.86$. Like in the first trait, it was observed in 
the second trait concerning spatial inaccessibility - too far to travel - that the highest average concentration of unmet need for medical examination in the studied countries of the so called New European Union was observed for the social group with the levels of income (Q80_100), and with the highest level of education (ED5_8).

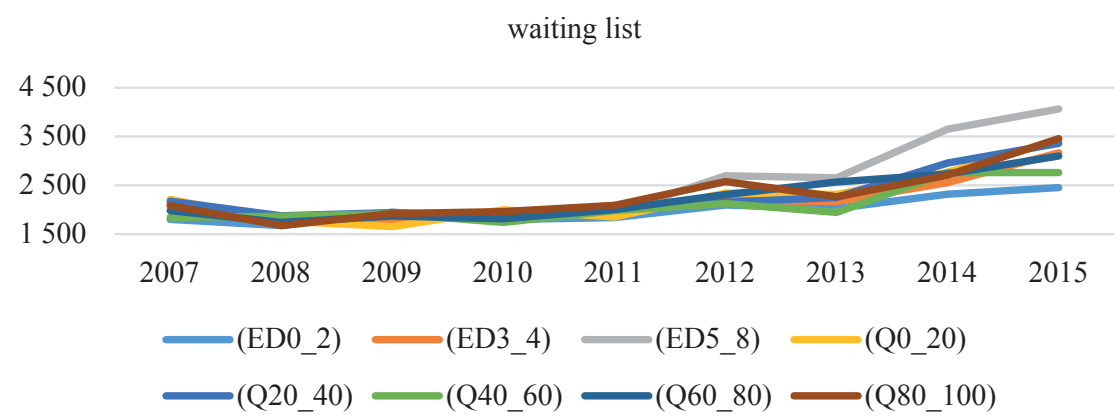

Figure 3. The value of the Herfindahl-Hirschman index concerning the unmet need for medical examination was observed for the trait due to long-time of waiting for an appointment - waiting list with division into categories of education level and income of natural persons in the years 2007-2015

Source: own study.

What is more, the average value of concentration for the $X_{\mathrm{ED} 2}$ variable is $\overline{H H I_{X_{F D 3}}}=2238.60$ and for the $X_{\mathrm{Q} 2}$ variable it is $\overline{H H I_{X_{Q 3}}}=2238.91$ and the highest average concentration of unmet need for medical examination in the studied countries of the so called New European Union was observed for the social group with the levels of income (Q80_100, and education (ED5_8).

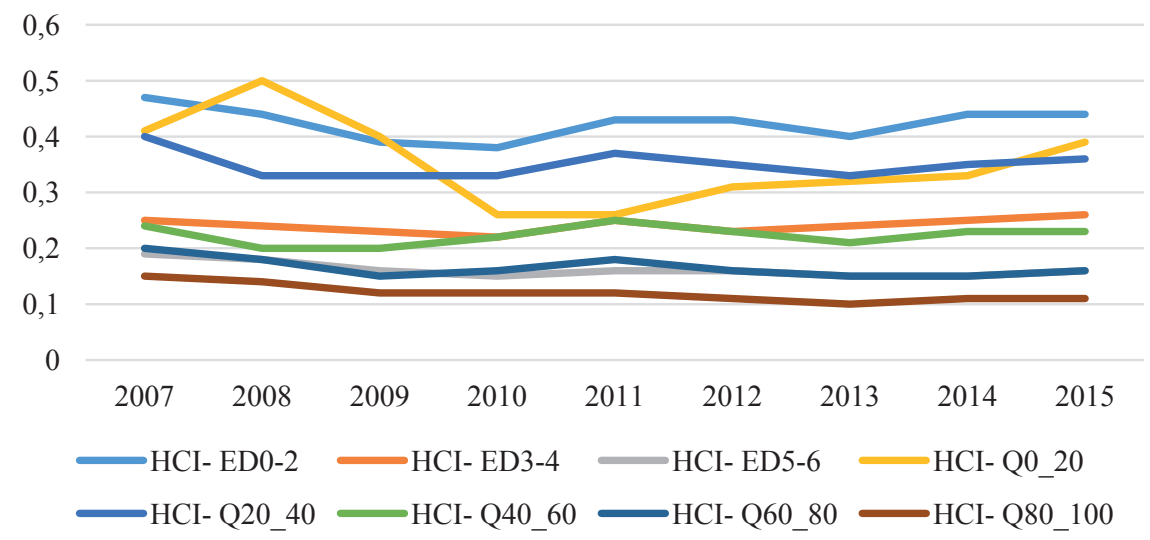

Figure 4. Value of the health concentration index with division of the level of education and income of natural persons in the years 2007-2015 into categories

Source: own study. 
Health concentration index was calculated with the use of survey data, inequality of the state of health determined by education as well as income, and variables for the countries of the so called New European Union were applied in the form of SRH - self-rated health), i.e.

self-perceived health by educational attainment level,

self-perceived health income quintile.

In the study, the indexes assume values from 0.10 to 0.50 . The values are the highest in the social group with the lowest level of income (Q0_20) and education (ED0_2).

To sum up, the correlation index was calculated in order to check the relation between inequality in unmet health needs determined by the HHI index and the state of health of a population determined by the HCI rate.

Table 2. Spearman rank correlations between concentration of the health care accessibility in the years 2007-2015 and the level of health care concentration depending on income and education in populations

\begin{tabular}{|l|c|c|c|c|c|c|}
\hline \multirow{2}{*}{ Index } & \multicolumn{2}{|c|}{ HCI-ED5-8 } & \multicolumn{2}{c|}{ HCI-Q60_80 } & \multicolumn{2}{c|}{ HCI-Q80_100 } \\
\cline { 2 - 7 } & $r_{S}$ & $p$ & $r_{S}$ & $p$ & $r_{S}$ & $p$ \\
\hline${ }_{3-4} H H I_{X_{E D 1}}$ & -0.6473 & 0.0595 & & & & \\
\hline${ }_{5-8} H H I_{X_{E D 1}}$ & -0.7271 & 0.0265 & & & & \\
\hline $80 \_100 H H I_{X_{Q 1}}$ & & & 0.7105 & 0.0320 & & \\
\hline${ }_{40 \_60} H H I_{X_{Q 2}}$ & & & 0.6671 & 0.0496 & & \\
\hline${ }_{40 \_}{ }_{60} H H I_{X_{Q 3}}$ & & & & & -0.6900 & 0.0396 \\
\hline${ }_{80 \_100} H H I_{X_{Q 3}}$ & & & & & -0.7418 & 0.0221 \\
\hline
\end{tabular}

Source: own study

The Spearman rank correlation was analyzed in order to verify the study problem. Results of the analysis of the existing correlations among concentrations of the variables $\mathrm{X}_{\mathrm{ED} 1}, \mathrm{X}_{\mathrm{Q} 1}, \mathrm{X}_{\mathrm{ED} 2}, \mathrm{X}_{\mathrm{Q} 2}, \mathrm{X}_{\mathrm{ED} 3}, \mathrm{X}_{\mathrm{Q} 3}$ in social groups with high level of education or income showed statistically significant strong correlations (Table 2).

Examination of the existing correlations shows that along with the increasing inequalities of unmet health needs in the social group with a high level of education (ED5_8) for the $X_{\mathrm{ED} 1}$ trait, too expensive - the concentration in the state of health ( $\underline{\mathrm{r}}_{\mathrm{s}}=$ $-0.7271 ; p<0.05)$ diminishes, and the same happens for the same trait with medium level of education (ED4_5) $\left(r_{x y}=-0.6473 ; p<0.01\right)$.

What is more, a similar situation was observed when analyzing studies of correlations existing in the social group with high level of income (Q80_100) for the trait $X_{\mathrm{Q} 3}$ waiting list $\left(r_{s}=-0.7418 ; p<0.05\right)$ and for the same trait with the level $\left(\mathrm{Q} 40 \_60\right)\left(\mathrm{r}_{\mathrm{xy}}=-0.6900 ; \mathrm{p}<0.05\right)$. A study of the correlation indicated a statistically 
important high relationship. The above results allow to accept the formulated hypothesis (H1) about the relation between the need to meet the needs in health care, depending on the level of education or income of a population and the state of health inequalities in the countries of the so called New European Union.

\section{Conclusions}

The relation between the unmet aspects of health needs depending on the level of education or income of a population and the state of health inequalities in the countries of the so called New European Union are analyzed in this paper. The formulated hypothesis about the impact of high level of education or income, which is connected with health literacy, skills in meeting health needs was explicitly confirmed during the analysis of concentration of the three traits of health care accessibility, which showed that the highest level of concentration indicating a conscious need for taking advantage of specialist medical examinations necessary for the improvement of health was observed in social groups with high education (ED5_8) and income (Q80_100), Q60_80). The analysis confirmed also that an inequality in the state of health of a population depends on accessibility of health care. Although access to health care is only one and certainly not the most important factor determining the state of health, the study confirmed that education and ability in meeting health needs is the necessary factor in eliminating health inequalities in a population.

Inequalities in access to health are constantly studied all over the world and their purpose is not only diagnosing the existing differences, but promoting improvement of the quality of health care taking into account justified health needs of local communities as well. Further studies be the authoress in the field of accessibility of health care are aimed at studying inequalities in accessibility, described by implemented and assessment of the effectiveness of the health care system, described by differences in health care needs.

\section{References}

Ad Hoc Committee on Health Literacy for the Council on Scientific Affairs AMA, 1999, Health literacy: Report of the council on scientific affairs, Journal of American Medical Association, vol. 281, no. 6, pp. 552-557, doi: 10.1001/jama.281.6.552.

Adams R.J., Stocks N.P., Wilson D.H., Hill C.L., Gravier S., Kickbusch I., Beilby J.J., 2009, Health literacy. A new concept for general practice?, Australian Family Physician, vol. 38, no. 3, pp. $144-147$.

Ataguba J.E., Day C., McIntyre D., 2014, Monitoring and evaluating progress towards universal health coverage in South Africa, PLoS Med, vol. 11, no. 9, e1001686, https://doi.org/10.1371/journal. pmed.1001686.

Bem A., Ucieklak-Jeż P., Prędkiewicz P., 2013, Effects of inequalities in access to health services in rural areas in Poland, Management Theory and Studies for Rural Business and Infrastructure Development, Aleksandras Stulginskis University, vol. 35, no. 4, pp. 491-497. 
Chen Z., Eastwood D.B., Yen S.T., 2007, A decade's story of childhood malnutrition inequality in China: Where do you live does matter, China Economic Review, vol. 18, pp. 139-154.

Chen Z., Roy K., 2009, Calculating concentration index with repetitive values of indicators of economic welfare, Journal of Health Economics, vol. 28, no. 1, pp. 169-175.

European Commission, 2007, Together for health: A strategic approach for the EU 2008-2013, Com 2007630 final.

Fine L.J., Philogene, G.S., Gramling R., Coups E.J., Sinha S., 2004, Prevalence of multiple chronic disease risk factors: 2001 National Health Interview Survey, American Journal of Preventive Medicine, vol. 27, no. 2, pp. 18-24.

Freedman D.A., Bess K.D., Tucker H.A., Boyd D.L., Tuchman A.M., Wallston K.A., 2009, Public health literacy defined, American Journal of Preventive Medicine, vol. 36, no. 5, pp. 446-451, doi: 10.1016/j.amepre.2009.02.

Fukushige M., Ishikawa N., Maekawa S., 2012, A modified Kakwani measure for health inequality, Health Economics Review, vol. 2, no. 1.

Ginevičius R., Čirba S., 2007, Determining market concentration, Journal of Business Economics and Management, vol. 8, no. 1, pp. 3-10,. doi.org/10.1080/16111699.2007.9636147.

Ishikawa H., Yano E., 2008, Patient health literacy and participation in the health-care process, Health Expectations, vol. 11, no. 2, pp. 113-122, doi: 10.1111/j.1369-7625.2008.00497.x.

Kakwani N.C., Wagstaff A., van Doorslaer E., 1997, Socioeconomic inequalities in health: measurement, computation, and statistical inference, Journal of Econometrics, 77, pp. 87-103, https://doi. org/10.1016/S0304-4076(96)01807-6.

Kickbusch I., Wait S., Maag D., Banks I., 2006, Navigating Health: The Role of Health Literacy. Alliance for Health and the Future, International Longevity Centre, London.

Koolman X., van Doorslaer E., 2004, On the interpretation of a concentration index of inequality, Health economics, 13(7), pp. 649-656.

Korzeniowska E., Puchalski K. (eds.), 2010, Nisko wyksztatceni pracownicy a zdrowie - wyzwania dla edukacji zdrowotnej, Rīga Stradiņš University, Riga.

Mancuso J.M., 2008, Health literacy: A concept/dimensional analysis, Nursing and Health Sciences, 10, pp. 248-255, doi: 10.1111/j.1442-2018.2008.00394.x.

Mangalore R., Knapp M., Jenkins R., 2007, Income-related inequality in mental health in Britain: The concentration index approach, Psychological Medicine, vol. 37, no. 7, pp. 1037-1045.

Matczak M., 2016, Wykorzystanie strukturalnych miar koncentracji w analizie konkurencyjności rynku morskich przewozów kontenerowych, Problemy Transportu i Logistyki, nr 3 (35), pp. 111-119, doi: 10.18276/ptl.2016.35-11.

Meilak C., 2008, Measuring export concentration: The implications for small states, Bank of Valletta Review, vol. 37, pp. 35-48.

Nielsen-Bohlman L., Panzer A.M., Kindig D.A. (eds.), 2004, Health Literacy: A Prescription to End Confusion, The National Academies Press, Washington, DC.

Nutbeam D., 1998, Health Promotion Glossary. Health Promotion International, vol. 13, pp. 349-364, doi: 10.1093/heapro/13.4.349.

Nutbeam D., 2000, Health literacy as a public goal: A challenge for contemporary health education and communication strategies into the 21st century, Health Promotion International, vol. 15, no. 3 , pp. 259-267, doi: 10.1093/heapro/15.3.259.

Paasche-Orlow M.K., Wolf M.S., 2007, The causal pathways linking health literacy to health outcomes, American Journal of Health Behavior, vol. 31 (Suppl. 1), pp. 19-26.

Pan J., Qin X., Li Q., Messina J.P., Delamater P.L., 2015, Does hospital competition improve health care delivery in China?, China Economic Review, vol. 33, no. 4: 201, doi: 10.3389/fpubh.2016.00201.

Pavlekovic G. (ed.), 2008, Health Literacy. Programmes for Training on Research in Public Health for South Eastern Europe, vol. 4: Health Promotion and Disease Prevention: A Handbook for Teachers, Researchers, Health Professionals and Decision Makers, pp. 463-466. 
Preston S.H., 1975, The changing relation between mortality and level of economic development, Population Studies, vol. 29, no. 2, pp. 231-248.

Puchalski K., Korzeniowska E., 2011, Zróżnicowanie stosunku do edukacji zdrowotnej a wykształcenie. Polacy na tle pracowników z Hiszpanii, Łotwy i Słowenii, Zdrowie Publiczne i Zarządzanie-Zeszyty Naukowe Ochrony Zdrowia, vol. 9, no. 2), pp. 85-96, doi: 10.4467/20842627OZ.11.001.0338.

Rhoades S.A., 1993, The Herfindahl-Hirschman Index, Federal Reserve Bulletin, vol. 79, no. 3, pp. 188-189.

Rój J., 2016, Competition measurement of hospitals in Poland: The Herfindahl-Hirschman index approach, Ekonomika, vol. 95, no. 1, pp. 166-181, doi: 10.15388/Ekon.2016.1.9912.

Rootman I., Gordon-El-Bihbety D., 2008, A Vision for a Health Literate Canada, Canadian Public Health Association, Ottawa.

Sørensen K., Van den Broucke S., Fullam J., Doyle G., Pelikan J., Slonska Z., Brand H., 2012, Health literacy and public health: A systematic review and integration of definitions and models, BMC Public Health, vol. 12, no. 1, doi: 80.10.1186/1471-2458-12-80.

Ucieklak-Jeż P., 2016a, Health inequality determined by education and income in European countries, Prace Naukowe Akademii im. Jana Długosza w Częstochowie. Pragmata tes Oikonomias, nr 10, pp. 157-170, doi.org/10.16926/pto.2016.10.13.

Ucieklak-Jeż P., 2016b, Education and income as health determinants in Central-Eastern Europe, Prace Naukowe Akademii im. Jana Długosza w Częstochowie. Pragmata tes Oikonomias, nr 10, pp. 171-184, doi.org/10.16926/pto (14.10. 2016).

WHO, 2013, Handbook on health inequality monitoring with a special focus on low-and middle-income countries, World Health Organization, Geneva.

WHO, 2014, Social determinants of health, http://www.who.int/social_determinants/sdh_definition/en/ (6.11.2014).

World Bank, 2004, Quantitative Techniques for Health Equity Analysis: Technical Notes \#7, http:// www1.worldbank.org/prem/poverty/health/wbact/health eq tn07.pdf (14.10.2016).

Yost K.J., Webster K., Baker D.W., Choi S.W., Bode R.K., Hahn E.A., 2009, Bilingual health literacy assessment using the Talking Touchscreen/la Pantalla Parlanchina: Development and pilot testing, Patient Education and Counseling, vol. 75, no. 3, pp. 295-301, doi: 10.1016/j.pec.2009.02.020.

Zarcadoolas C., Pleasant A., Greer D.S., 2003, Elaborating a definition of health literacy: A commentary, Journal of Health Communication, vol. 8, no. 3, pp. 119-120.

Zarcadoolas C., Pleasant A., Greer D.S., 2005, Understanding health literacy: an expanded model, Health Promotion International, vol. 20, no. 2, pp. 195-203.

Zarcadoolas C., Pleasant A., Greer D., 2006, Advancing Health Literacy. A Framework for Understanding and Action, Jossey Bass, San Francisco. 